\title{
Changes in the composition and fatty acid profile of Najdi ewes' milk before and after weaning
}

\author{
A.M. Matar ${ }^{1}$, M. Ayadi ${ }^{1,2 \#}$, R. S. Aljumaah ${ }^{1}$, I. A. Nehdi ${ }^{3,4}$, H. M. Sbihi ${ }^{3}$, A. Souli ${ }^{2}$ \\ \& M. A. Abouheif ${ }^{1}$ \\ ${ }^{1}$ Department of Animal Production, College of Food and Agriculture Sciences, King Saud University, Riyadh, Saudi - \\ Arabia, P. O. Box 2460, Riyadh 11451 \\ ${ }^{2}$ Département de Biotechnologie Animale, Institut Supérieur de Biotechnologie de Beja, Université de Jendouba, \\ B.P. 382, Av. Habib Bourguiba, 9000 Beja, Tunisia \\ ${ }^{3}$ Chemistry Department, College of Science, King Saud University, P.O. BOX 2454, Riyadh 1145, Saudi Arabia \\ ${ }^{4}$ UR Physico-Chimie des Matériaux Solides, Chemistry Department, Science College, Tunis El Manar University, \\ 2092 Tunis, Tunisia
}

(23 May 2016; Accepted 6 March 2017; First published online 5 April 2017)

Copyright resides with the authors in terms of the Creative Commons Attribution 4.0 South African Licence.
See: http://creativecommons.org/licenses/by/4.0/za
Condition of use: The user may copy, distribute, transmit and adapt the work, but must recognise the authors and the South African
Journal of Animal Science.

\begin{abstract}
This trial aimed to study the changes in the yield, composition, and fatty acid (FA) profile of ewes' milk during suckling and milking periods. Nineteen multiparous Najdi ewes were kept under identical management and feeding conditions during a 12-week trial that was divided into two periods. Milk samples were collected on each sampling day from the total yield during the suckling (3rd, 6th, and 9th week) and milking (12th week) periods. The milk yield and the total solids, fat, protein, and lactose contents of the milk remained constant throughout the suckling weeks, but the protein content increased and milk yield and lactose content decreased after weaning. There were no differences in milk saturated FA (SFA), unsaturated FA (UFA), and monounsaturated FA (MUFA) contents during the suckling and milking periods, whereas the polyunsaturated FA content increased during the milking period. There were no differences in the individual milk SFA during the weeks of suckling, but the contents of caproic acid (C6:0), caprylic acid (C8:0), margaric acid (C17:0), and stearic acid (C18:0) decreased. However, myristic acid (C14:0), lauric acid (C12:0), and isomers of pentadecanoic (C15:0) acid increased during the milking period. The percentage of vaccenic acid $(\mathrm{C} 18: 1 \Delta 11 t)$, rumenic acid $(\mathrm{C} 18: 2 \Delta 9 c, 11 t$, conjugated linoleic acid (CLA)), $\omega-3$ FA group, and the atherogenicity index did not differ during the suckling period, but increased after weaning in the 12th week of lactation. This study demonstrated that weaning lambs in Najdi ewes is probably a factor that strongly affects milk traits by changing yield, composition, and FA profile.
\end{abstract}

Keywords: CLA, dairy ewes, milk fat, milk yield, stage of lactation

\#Corresponding author: mayadi@ksu.edu.sa, moez ayadi2@yahoo.fr

\section{Introduction}

Sheep play an important role in the agribusiness economy of Saudi Arabia, where the sheep population is close to 7.2 million (Ayadi et al., 2014). Rearing sheep for milk production is generally a tradition in the Middle East, and has recently been gaining importance in the dairy sector owing to its high dry matter content and exceptional nutritive value. Fatty acids (FAs) are important components of milk from a nutritional point of view for humans (Bouattour et al., 2007). Among the FAs found in milk, UFA, namely vaccenic acid (cis9, trans11-18:2), rumenic acid (trans 11-18:1), omega-3 ( $\omega-3)$ FA group, and CLA isomers, are considered beneficial to human health (Ellis et al., 2006). The FA composition of milk depends on both the consumed dietary FAs and the biohydrogenation activities in the rumen (Ayeb et al., 2015; Sinanoglou et al., 2015). Several studies have demonstrated that breed and dietary regime play pivotal roles in modulating the milk FA composition (Signorelli et al., 2008; De La Fuente et al., 2009; Mierlita et al., 2011a). However, studies on the effects of physiological factors such as parity, age, and stage of lactation on ovine milk FA are still scarce, and much of the literature focuses on caprine and bovine dairy animals.

To the best of the authors' knowledge, information about the milk FA profile of indigenous Najdi ewes is not available in the literature. The Najdi sheep is the most popular and predominant breed in the central province of Saudi Arabia. They are well adapted to the extreme hot summer conditions, are used for milk 
production under traditional Bedouin rearing conditions, and are classified as fat-tailed, carpet-wooled, and non-seasonal breeders. Ayadi et al. (2014) reported that Najdi ewes had immense potential for milk production under intensive production systems, yielding an average of $1.94 \mathrm{~L}_{\text {day }}{ }^{-1}$ during the first nine weeks of lactation. Alternative weaning systems that could spare larger amounts of milk for the commercial dairy industry have been sought by Najdi breeders. Thus, the objective of this experiment was to study the changes in the FA profile of milk during the suckling and milking periods in Najdi ewes kept in the same flock and reared under identical management and dietary practices.

\section{Materials and Methods}

Nineteen multiparous Najdi ewes, which had an average age of approximately three years and average bodyweight of 60-65 kg, with healthy udders, were used for this study. All ewes were in the second lactation period and had lambed singles. Ewes were allocated to four semi-open sheds (groups) to ensure close observation. They were managed uniformly, without any discernible variation in nutrition or environmental condition throughout the study, and fed commercial pellets $\left(1.5 \mathrm{~kg} \mathrm{ewe}^{-1}\right.$ day $\left.^{-1}\right)$ in addition to ad libitum alfalfa hay. The commercial pellet was analysed for crude protein (CP), ether extract (EE), and ash according to AOAC (1990). The neutral detergent fibre (NDF) and acid detergent fibre (ADF) were determined according to Van Soest et al. (1991). The chemical composition on dry matter basis (DM) was $14.5 \%$ (CP), $1.2 \%$ (EE), 42.9\% NDF, 14.2\% ADF, 7.5\% ash, and $2.78 \mathrm{Mcal}_{\mathrm{kg} \mathrm{DM}}{ }^{-1}$ metabolizable energy (ME). Water and mineralized salt blocks were freely available to the ewes. The experiment was carried out from January to March $2013\left(22{ }^{\circ} \mathrm{C}\right.$ and $10 \%$ relative humidity) to avoid hot summer conditions. The experimental protocol for handling ewes was approved by the Ethics Committee of King Saud University, Riyadh (latitude $24^{\circ} 48^{\prime} \mathrm{N}$ and longitude $46^{\circ} 31^{\prime} \mathrm{E}$ ), Saudi Arabia.

All lambs were allowed to suckle freely throughout the first nine weeks of lactation (suckling period). Afterwards, lambs were weaned and the ewes were hand-milked once daily until the end of the 12th week of lactation (milking period). During the suckling period, the milk yield potential in a 24-hour period was estimated in the 3rd, 6th, and 9th weeks of lactation. Milk yield potential was calculated as 6 times the milk yield in 4-hour period, according to the methodology of Doney et al. (1979). To ensure complete emptying of the udder, two-IM injections of oxytocin (4 IU/ewe) were given at 4-hour intervals. After weaning, the milk yield was recorded in the 12th week of lactation (milking period). The milking routine included hand milking, with the udder cleaned, hand stripping, and dipping the teats in iodine solution after milking. All ewes were under close veterinary supervision and no clinical signs of mastitis were detected during the study.

Milk samples $(60 \mathrm{~mL})$ were randomly collected from the total milk yield of each individual ewe during the suckling (3rd, 6th, and 9th weeks) and milking (12th week) periods. Samples were mixed for about 15 seconds, then immediately placed in an ice box, transferred to the laboratory, and kept frozen at $-4^{\circ} \mathrm{C}$ until further analyses in the same week. Approximate chemical analyses, including fat, protein, lactose, and total soluble solids percentages, were performed for all milk samples using a Milko Scan (Minor Type 78100, Foss Electric, Denmark).

Milk samples for FA analysis were defrosted in a water bath at $35^{\circ} \mathrm{C}$. Fatty acids from sheep milk fat (SMF) were extracted using the procedures recommended by Luna et al. (2005). Milk samples were centrifuged at $4000 \mathrm{rpm}$ for eight minutes at $4{ }^{\circ} \mathrm{C}$, followed by floating globule collection. The collected SMFs were preserved at $-20^{\circ} \mathrm{C}$ till analysis. The analysis of SMF was performed using standard techniques and reagents. Triacylglycerols in SMF were saponified and converted to fatty acid methyl esters (FAMEs) using the method reported by Nehdi et al. (2013). Fatty acid methyl esters were obtained by adding $1 \mathrm{~mL}$ hexane and $200 \mu \mathrm{L}$ of $2 \mathrm{M}$ sodium methoxide to $40 \mathrm{mg}$ fat fraction. The fat mixture was heated in a water bath at 50 ${ }^{\circ} \mathrm{C}$ for a few seconds, and then $200 \mu \mathrm{L}$ of $2 \mathrm{M} \mathrm{HCl}$ were added. A 1- $\mu \mathrm{L}$ aliquot of the top layer was used for analysis. The identification and quantification of FAMEs were performed using a gas chromatography-mass spectrometry ultra-instrument (GCMS-QP2010, Shimadzu, Kyoto, Japan) and an Rtx-1 column (30 m × 0.25 $\mathrm{mm}$ i.d., $0.25 \mu \mathrm{m}$ film thickness), with helium as the carrier gas at a flow rate of $1.41 \mathrm{~mL} \mathrm{~min}{ }^{-1}$. The oven temperature was increased from 150 to $180^{\circ} \mathrm{C}$ at a rate of $15^{\circ} \mathrm{C} \mathrm{min}{ }^{-1}$, followed by an increase to $210^{\circ} \mathrm{C}$ at $1{ }^{\circ} \mathrm{C} \mathrm{min}{ }^{-1}$. The temperatures of the injector and detector were $220^{\circ} \mathrm{C}$ and $275^{\circ} \mathrm{C}$, respectively. For gas chromatography-mass spectrometry detection, an electron ionization system with an ionization energy of $70 \mathrm{eV}$ was used. The ion source temperature was $230{ }^{\circ} \mathrm{C}$ and the interface temperature was $280{ }^{\circ} \mathrm{C}$. The FAMEs were identified by comparing their relative retention times and mass spectra with those of standards (main components) using the Wiley 8 library data of the main system. The relative percentages of the individual FA were calculated based on the ratios of the peak areas of the FA species to the total peak area of all the FA in the fat sample.

Data collected for milk yield, milk composition, and milk FA profiles over the course of this experiment were processed using the PROC MIXED procedures for repeated measurements in SAS (version 9.1, SAS 
Inst. Inc., Cary, NC, USA). All percentage values were transformed to arcsine before the analyses. The statistical model was: $Y_{\mathrm{ijk}}=\mu+W_{\mathrm{i}}+\mathrm{p}_{\mathrm{ij}}+\mathrm{e}_{\mathrm{ijk}}$,

Where $Y_{i j k}$ is the observation of $k^{\text {th }}$ ewe in the $j^{\text {th }}$ group of $i^{\text {th }}$ lactation week $(k=1,2, \ldots 4$, or $5 ; j=1,2, . .4 ; i=1$, $2, \ldots 4) ; \mathrm{M}=$ overall mean, $W_{i}=$ the fixed effect of the $\mathrm{i}^{\text {th }}$ lactation week (suckling period $=3 \mathrm{rd}, 6$ th, 9 th; milking period $=12$ th),$p_{i j}=$ the random effect of $j^{\text {th }}$ group of ewes in the $i^{\text {th }}$ lactation week, $e_{i j k}=$ the random error association with each observation. The differences between means were determined using least significant difference (LSD). The level for statistical significance was set at $P<0.05$.

\section{Results and Discussion}

The estimated daily milk yield did not differ during the nine weeks of the suckling period, when it averaged $2.04 \mathrm{~L} \mathrm{day}^{-1}$, but decreased $(P<0.05)$ by $84 \%$ after weaning to $0.32 \mathrm{~L} \mathrm{day}^{-1}$ in the 12 th week of lactation (Table 1). Similar reductions in the daily milk yield, ranging from $30 \%$ to $75 \%$, have been reported in several sheep breeds (Gargouri et al., 1993; Ayadi et al., 2011, 2014).The drop in daily milk productivity after weaning could be explained by the partial disappearance of the stimulus caused by the transition from suckling to milking. According to Marnet (1997), the decrease in milk yield during weaning might be explained by the reduced emptying frequency and to a lesser degree by dam-lamb separation. When extended emptying intervals were practised, alveolar drainage decreased and intramammary pressure increased, all of which had negatively affected milk secretion, and eventually could have decreased milk yield (Castillo et al., 2009). The inconsistencies in daily milk yield dropping rates in this trial compared with other studies are probably due to the milking management, breed differences, and variation in cisternal size.

The week of lactation did not affect the milk fat and total milk solid contents, whereas milk protein percentage increased $(P<0.05)$ gradually from $3.7 \%$ in the 3 rd week to $4.86 \%$ in the 12 th week of lactation (Table 1). The increased milk protein content during lactation was in agreement with the results obtained by Gargouri et al. (1993) and Ayadi et al. (2014), who found that milk protein content during the suckling period was lower than in the milking period. The average milk fat percentage $(4.41 \%)$ in this trial was similar to the value reported by Abd Allah et al. (2011) in Chios ewes and Ayadi et al. (2014) in Najdi ewes, but was lower than the values (6.2-7.4\%) reported by Nudda et al. (2002) in Awassi ewes and Castillo et al. (2009) in Lacaune and Manchega ewes. Breed differences and diet could explain the discrepancies in fat percentages between these results and those of previous studies. Generally, the average percentage of total milk solids obtained for Najdi ewes in this study was lower than the reported values (13.5\% vs. $16-19 \%)$ in the literature (Castillo et al., 2009; Abd Allah et al., 2011). The milk lactose content did not change throughout the suckling period, averaging $4.97 \%$, but it decreased $(P<0.05)$ to $3.11 \%$ in the 12 th week of lactation. Ayadi et al. (2014) found that the average percentage of lactose during the suckling period was higher than in the milking period. Similarly, Yilmaz et al. (2011) reported that the lactose content at the beginning of lactation was higher than in the late stage of lactation.

Table 1 Means ( \pm SEM) of milk yield and milk composition of Najdi ewes during suckling and milking periods

\begin{tabular}{lccccc}
\hline \multirow{2}{*}{ Trait } & \multicolumn{3}{c}{ Suckling period $^{1}$} & Milking period $^{\mathbf{2}}$ & \multirow{2}{*}{ SEM $^{\mathbf{3}}$} \\
\cline { 2 - 5 } & 3rd week & 6th week & 9th week & 12th week & \\
\hline Milk yield, L day ${ }^{-1}$ & $2.07^{\mathrm{a}}$ & $2.04^{\mathrm{a}}$ & $2.01^{\mathrm{a}}$ & $0.32^{\mathrm{b}}$ & 0.22 \\
ECM $^{4}$ & $2.43^{\mathrm{a}}$ & $2.01^{\mathrm{a}}$ & $2.19^{\mathrm{a}}$ & $0.41^{\mathrm{b}}$ & 0.19 \\
Fat \% $_{\text {Protein \% }}$ & 4.60 & 4.28 & 4.18 & 4.59 & 0.45 \\
Lactose \% & $3.70^{\mathrm{b}}$ & $3.81^{\mathrm{b}}$ & $3.99^{\mathrm{b}}$ & $4.86^{\mathrm{a}}$ & 0.16 \\
Total solid \% & $4.76^{\mathrm{a}}$ & $5.09^{\mathrm{a}}$ & $5.06^{\mathrm{a}}$ & $3.11^{\mathrm{b}}$ & 0.20 \\
& 13.75 & 12.97 & 13.62 & 13.76 & 0.40
\end{tabular}

${ }^{a, b, c}$ Means on the same row bearing different superscripts differ $(P<0.05)$

${ }^{1}$ Milk yield potential in a 24-hour period was calculated as 6 times the milk yield in 4-hour period

${ }_{2}^{2}$ Milk yield production in a 24-hour period was obtained by hand milking once a day

${ }^{3}$ SEM: standard error of mean

${ }^{4}$ Energy corrected milk $(E C M)=$ milk yield, $L_{\text {day }}{ }^{-1}(0.071+0.15 \times$ fat $(\%)+0.043 \times$ protein $(\%)+0.2224)$

No previous data on milk FA profile of Najdi ewes were available in the literature. Under the given analytical conditions, butyric acid (C4:0) could not be detected, owing to its elution with the solvent. The 
calculated values for the milk FA groups, $\omega-6 / \omega-3$ ratio, and atherogenicity index are shown in Table 2 . Milk FA groups during all weeks of the suckling and milking periods decreased in the order of SFA $>M U F A>P U F A$, which is in agreement with other studies in sheep (Mierlita et al., 2011a,b; Sinanoglou et al., 2015) and goats (Ayeb et al., 2015; Kuchtík et al., 2015). There were no differences in milk fat composition, in either SFA or in UFA groups during the suckling and milking periods. Higher values ( $>70 \%)$ of SFA were obtained in the milk fat of dairy Lacaune (Bouattour et al., 2007) than those values obtained from the indigenous Najdi ewes $(\leq 65 \%)$. These recorded values agree well with those reported by Kay et al. (2005), that the selection for milk yield increased the SFA percentage in the FA profile of milk in dairy cattle breeds. The smaller percentage of SFA in the milk fat of Najdi ewes seems to be beneficial in two ways: i) it might improve the cheese characteristics, as volatile organic compounds and secondary alcohol resulted mainly from the lipolysis of SFA (Engels et al., 1997), and ii) its role in benefits to human health, owing to their negative association with atherosclerosis (Ellis et al., 2006).

Table 2 Means ( \pm SEM) for characteristics of Najdi milk fat during suckling and milking periods (\% of total measured fatty acids)

\begin{tabular}{|c|c|c|c|c|c|}
\hline \multirow{2}{*}{ Trait } & \multicolumn{3}{|c|}{ Suckling period } & \multirow{2}{*}{$\begin{array}{c}\text { Milking period } \\
\text { 12th week }\end{array}$} & \multirow{2}{*}{ SEM $^{1}$} \\
\hline & 3rd week & 6th week & 9th week & & \\
\hline Saturated FA & 66.17 & 64.81 & 65.79 & 65.57 & 1.88 \\
\hline Unsaturated FA & 33.83 & 35.19 & 34.21 & 34.79 & 1.64 \\
\hline monounsaturated FA & 29.84 & 30.89 & 30.04 & 29.86 & 1.42 \\
\hline polyunsaturated FA & $3.99^{c}$ & $4.30^{\mathrm{b}}$ & $4.17^{\mathrm{bc}}$ & $4.93^{\mathrm{a}}$ & 0.26 \\
\hline$\omega-6 \mathrm{FA}^{2}$ & 2.68 & 2.92 & 2.82 & 2.74 & 0.34 \\
\hline$\omega-3 F A^{2}$ & $0.84^{b}$ & $0.85^{b}$ & $0.77^{\mathrm{b}}$ & $1.35^{\mathrm{a}}$ & 0.09 \\
\hline$\omega-6 / \omega-3$ & $3.19^{b}$ & $3.44^{\mathrm{ab}}$ & $3.66^{a}$ & $2.03^{c}$ & 0.42 \\
\hline$\Delta^{9}$-desaturase ratio, $C L A^{3}$ & $0.35^{b}$ & $0.36^{b}$ & $0.37^{a b}$ & $0.41^{\mathrm{a}}$ & 0.01 \\
\hline Atherogenicity index ${ }^{4}$ & $2.21^{b}$ & $2.07^{b}$ & $2.30^{b}$ & $2.45^{a}$ & 0.61 \\
\hline \multicolumn{6}{|c|}{$\begin{array}{l}\text { a,b,c Means on the same row bearing different superscripts differ }(P<0.05) \\
{ }^{1} \text { SEM: standard error of mean } \\
{ }^{2} \omega-6=\text { omega- } 6 \text { FA; } \omega-3=\text { omega-3 FA } \\
{ }^{3} \Delta^{9} \text {-desaturase ratios according to Kelsey et al. }(2003) \text { as product of } \Delta 9 \text {-desaturase/(product of } \Delta^{9} \text {-desaturase }+ \\
\text { substrate of } \Delta^{9} \text {-desaturase) } \\
{ }^{4} \text { Atherogenicity index }=[C 12: 0+(4 \times C 14: 0)+C 16: 0] /(M U F A+\omega 6+\omega 3) \\
\text { FA= fatty acids; } C L A=\text { conjugated linoleic acids; MUFA }=\text { monounsaturated fatty acids }\end{array}$} \\
\hline
\end{tabular}

Within the SFA group (Table 3), palmitic acid (C16:0), myristic acid (C14:0), and stearic acid (C18:0) had the highest percentages in both the suckling and the milking periods, with average values of 28.6, 11.0, and $10.6 \%$, respectively, of total FA content. Similar to these findings, it was reported by others that palmitic and myristic acids constituted the highest percentages of milk total FA in sheep (Mierlita et al., 2011a,b; Sinanoglou et al., 2015), goat (Kuchtík et al., 2015) and cattle milk (Wang et al., 2013). Milk fat stearic acid in Najdi milk had higher values than those reported by Mierlita et al. (2011a) for Spanca and Turcana breeds (7.8\%) of Romania, and Sinanoglou et al. (2015) for Karagouniko (5.6-6.9\%) and Chios breeds (5.4-8\%) of Greece. On other hand, stearic acid in Najdi ewes had the lowest percentage of the total FA composition of those reported by Signorelli et al. (2008) and Mierlita et al. (2011b) in various sheep breeds (14.7-19.6\%). The discrepancies can be explained by the variation in dietary amount of polyunsaturated FA (PUFA), biohydrogenation processes in the rumen, and variation in the enzymes involved in de novo SFA synthesis in the mammary glands. It was reported that $40 \%$ of the stearic acid extracted from the blood into the mammary glands is converted to oleic acid to preserve milk fluidity (Chilliard et al., 2000).

There were no differences in the total individual milk SFA during the weeks of suckling, but the caproic acid (C6:0), caprylic acid (C8:0), margaric acid (C17:0), and stearic acid contents decreased $(P<0.05)$ in the 12th week (milking period), whereas myristic (C14:0), lauric (C12:0), and isomers of pentadecanoic $(C 15: 0)$ acid percentages increased $(P<0.05)$. The decrease in the stearic acid during the milking period can be due 
to a reduction in the efficiency of rumen biohydrogenation or an increase in $\Delta^{9}$-desaturase activity in the mammary glands (Mierlite et al., 2011a).

Table 3 Mean ( \pm SEM) of fatty acid profiles of Najdi milk fat during suckling and milking periods (\% of total measured fatty acids)

\begin{tabular}{|c|c|c|c|c|c|}
\hline \multirow[b]{2}{*}{ Fatty acid } & \multicolumn{3}{|c|}{ Suckling period } & \multirow{2}{*}{$\begin{array}{c}\text { Milking period } \\
12^{\text {th }} \text { week }\end{array}$} & \multirow[b]{2}{*}{ SEM $^{1}$} \\
\hline & $3^{\text {rd }}$ week & $6^{\text {th }}$ week & $9^{\text {th }}$ week & & \\
\hline C6:0 & $1.38^{\mathrm{a}}$ & $1.34^{\mathrm{a}}$ & $1.41^{\mathrm{a}}$ & $1.10^{\mathrm{b}}$ & 0.11 \\
\hline C8:0 & $1.58^{\mathrm{ab}}$ & $1.67^{\mathrm{a}}$ & $1.75^{\mathrm{a}}$ & $1.40^{\mathrm{b}}$ & 0.18 \\
\hline C10:0 & 4.93 & 4.74 & 4.52 & 4.51 & 0.64 \\
\hline C12:0 & $4.42^{\mathrm{b}}$ & $4.56^{\mathrm{b}}$ & $4.34^{\mathrm{b}}$ & $5.16^{a}$ & 0.45 \\
\hline $\mathrm{C} 14: 0$ & $10.21^{b}$ & $9.90^{b}$ & $11.27^{a b}$ & $12.59^{a}$ & 0.71 \\
\hline C15:0 & 0.21 & 0.16 & 0.15 & 0.19 & 0.03 \\
\hline iso $\mathrm{C} 15: 0^{2}$ & $0.57^{\mathrm{b}}$ & $0.58^{b}$ & $0.62^{b}$ & $0.76^{a}$ & 0.08 \\
\hline anteiso $\mathrm{C} 15: 0^{3}$ & $0.23^{\mathrm{b}}$ & $0.34^{b}$ & $0.34^{\mathrm{b}}$ & $0.58^{a}$ & 0.04 \\
\hline C16:0 & 28.96 & 28.00 & 28.34 & 28.95 & 0.98 \\
\hline iso $\mathrm{C} 16: 0^{2}$ & 0.19 & 0.21 & 0.22 & 0.22 & 0.03 \\
\hline $\mathrm{Cl} 6: 1$ cis 6 & 0.23 & 0.27 & 0.32 & 0.31 & 0.12 \\
\hline C16:1 cis 9 & 0.91 & 0.98 & 1.00 & 0.99 & 0.12 \\
\hline $\mathrm{C} 17: 0$ & $0.95^{a}$ & $0.88^{a}$ & $0.86^{a}$ & $0.68^{b}$ & 0.07 \\
\hline iso $\mathrm{C} 17: 0^{2}$ & 0.31 & 0.42 & 0.38 & 0.34 & 0.05 \\
\hline anteiso $\mathrm{C} 17: 0^{3}$ & 0.31 & 0.33 & 0.32 & 0.35 & 0.04 \\
\hline C18:0 & $11.67^{\mathrm{a}}$ & $11.39^{a}$ & $11.03^{\mathrm{a}}$ & $8.50^{b}$ & 0.55 \\
\hline C18:1 cis 9 & 24.48 & 25.20 & 24.38 & 24.03 & 1.46 \\
\hline C18:1 trans 11 & $0.87^{\mathrm{b}}$ & $0.95^{b}$ & $1.00^{b}$ & $1.21^{\mathrm{a}}$ & 0.21 \\
\hline C18:2 cis 9 cis 12 & $2.40^{\mathrm{a}}$ & $2.53^{a}$ & $2.52^{\mathrm{a}}$ & $2.25^{b}$ & 0.16 \\
\hline C18:2 cis9 trans11 & $0.47^{\mathrm{b}}$ & $0.53^{b}$ & $0.58^{b}$ & $0.84^{\mathrm{a}}$ & 0.09 \\
\hline C18:3 cis9 cis 12 cis 15 & 0.50 & 0.47 & 0.40 & 0.45 & 0.06 \\
\hline $\mathrm{C} 20: 0$ & 0.25 & 0.29 & 0.24 & 0.24 & 0.08 \\
\hline C20:4 cis5 cis8 cis 11 cis 14 & $0.28^{b}$ & $0.39^{\mathrm{ac}}$ & $0.30^{\mathrm{ab}}$ & $0.49^{\mathrm{ac}}$ & 0.13 \\
\hline C20:4 cis8 cis 11 cis 14 cis 17 & $0.34^{b}$ & $0.38^{b}$ & $0.37^{b}$ & $0.90^{\mathrm{a}}$ & 0.24 \\
\hline Others & 3.35 & 3.49 & 3.34 & 3.32 & 0.47 \\
\hline
\end{tabular}

$\overline{a, b, c}$ Means on the same row bearing different superscripts differ $(P<0.05)$.

1 : SEM: Standard error of the mean

2: iso C15:0 = 13-Methyltetradecanoic acid; iso C16:0 = 14-Methylpentadecanoic acid; iso C17:0 = 15-

Methylhexadecanoic acid

3: anteiso C15:0 = 12-Methyltetradecanoic acid; anteiso C17:0 = 14-Methylhexadecanoic acid

The total MUFA did not change with the advance in lactation weeks, whereas the total of PUFA increased $(P<0.05)$ in the 12th week during the milking period (Table 2). The increased PUFA percentage in the milk fat is considered favourable to human health, particularly in reducing the risk of cardiovascular diseases. The average MUFA percentage in Najdi milk fat (30.2\%) was comparable with the value reported by Bouattour et al. (2007) for Lacauna and Manchega, and Mierlita et al. (2011a) for Turcana, but was higher than those reported for other sheep breeds (Mierlita et al., 2011b; Sinanoglou et al., 2015). Vaccenic acid $(C 18: 1 \Delta 11 t)$ percentage increased $(P<0.05)$ only during the milking period. As all milking ewes were offered the same diet, the increased vaccenic percentage in milk fat in this period can be explained by the decreased activity of rumen biohydrogenation. This assumption is supported by a lower stearic acid percentage, which is the product of biohydrogenation of vaccenic acid (Mierlite et al., 2011a; Wang et al., 
2013). Generally, the average vaccenic acid values during suckling and milking periods were 0.94 and $1.21 \%$, respectively. These values in Najdi milk fat were lower than those reported by several studies on sheep (3.6-7\%) (Bouattour et al., 2007; Mierlita et al., 2011a b) and dromedary camel (2.8\%) (Ayadi \& Casals, 2009), but were comparable with those mentioned for Tunisian goats (0.61\%) (Ayeb et al., 2015) and cows (1.4-1.8\%) (Ellis et al., 2006; Wang et al., 2013). The $\alpha$-linolenic acid (C18:3 $\Delta 9 \mathrm{c}, 12 \mathrm{c}, 15 \mathrm{c})$, which is a member of the $\omega-3$ FA group, is primarily of dietary origin, and its concentration in milk depends on its amount in the rumen (De La Fuente et al., 2009). Therefore, feeding the milking ewes with the same diet throughout the trial was probably the reason behind the non-significant differences in $\alpha$-linolenic acid percentages. The increased $(P<0.05) \omega-3 \mathrm{FA}$ in the 12th week of lactation was due to an increased $(P$ $<0.05)$ percentage of eicosatetraenoic acid $(C 20: 4 \Delta 8 \mathrm{c}, 11 \mathrm{c}, 14 \mathrm{c}, 17 \mathrm{c})$. Nutritionists have focused on the ratio between $\omega-6$ and $\omega-3$ FA in the diet. A high ratio is considered a risk factor for type-2 diabetes and coronary heart disease (Ellis et al., 2006). The $\omega-6 / \omega 3$ FA ratio in Najdi milk attained its lowest level after weaning (2.03:1) 9Table 2). However, this value was within that ratio recommended for human diet (2:1 to $4: 1$; Sretenovic et al., 2009).

Lactation during the suckling period had no effect on the percentage of rumenic acid (c9,t11-18:2), which represents 75 to $90 \%$ of the total CLA isomers (Luna et al., 2005). However, the rumenic acid in milk fat increased $(P<0.05)$ in the 12th week during the milking period. This result agreed with those obtained as lactation progressed in Merino, Tsigay, Turcana (Mierlita et al., 2011b), and Chios breeds (Sinanoglou et al., 2015). On the other hand, other studies reported no changes in the CLA percentage in milk fat during lactation of Karagouniko sheep (Sinanoglou et al., 2015) and cows (Kelsey et al., 2003). The higher percentage of rumenic acid in milk fat during the milking period was probably due to the increased $(P<0.05)$ of $\Delta^{9}$-desaturase enzyme activity, which was indicated by a higher content of vaccenic acid, which is the precursor of rumenic acid, and a higher $\Delta^{9}$-desaturase ratio (Table 2). Mierlita et al. (2011a) and Ayadi \& Casals (2009) found a strong positive correlation between vaccenic acid and CLA in milk fat. The $\Delta^{9}$ desaturase enzyme acts at mammary gland level to convert vaccenic acid into rumenic acid isomers.

Atherogenicity index is a criterion for the level and interrelationship of some milk FAs that may have atherogenic properties. A high atherogenicity index is assumed to be more detrimental to health. In particular, the myristic and palmitic acids should be controlled in the diet, as they are considered hyperlipidemic and are responsible for increasing the plasma cholesterol contents (Ulbricht \& Southgate, 1991). In this study, the atherogenicity index was increased $(P<0.05)$ only after weaning, to reach a value of 2.45 in the 12th week of lactation. A similar trend was reported for lactating ewes (De La Fuente et al., 2009; Mierlita et al., 2011b) and cows (Kelsey et al., 2003). Generally, the atherogenicity indices for Najdi milk during the lactation weeks (2.07-2.45) were in line with those reported for other international sheep breeds (Mierlita et al., 2011a b; Sinanoglou et al., 2015).

\section{Conclusion}

The results showed that weaning lambs at 9 weeks of age has considerable effects on the milk yield, composition, and FA profile. The most favourable changes that were observed in the milk FA profile for the benefit of consumers from a health point of view were the increases in PUFA, CLA, vaccenic acid, and $\omega-3$ FA group. Furthermore, the results will extend the authors' knowledge about the indigenous Najdi breed and its use for milk production under an intensive production system in Saudi Arabia.

\section{Acknowledgements}

The authors extend their appreciation to the Deanship of Scientific Research at King Saud University for funding this work through the research group project RGP-042.

\section{Authors' Contributions}

AMM conducted the research as part of his PhD. programme in animal production. AMM, MA, RSA and MAA designed and carried out the studies, interpreted the results and drafted the manuscript. AM and MAA supervised the animal experiment and interpreted the results for inclusion in the manuscript. AMM, MA, IAN and HMS participated in the milk composition and fatty acid analysis. AMM and RSA performed the statistical analysis. All authors read and approved the final manuscript.

\section{Conflict of Interest Declaration}

The authors have declared that there is no conflict of interests

\section{References}

Abd Allah, M., Abass, S.F. \& Allam, F.M., 2011. Factors affecting the milk yield and composition of Rahman and Chios sheep. Int. J. Livest. Prod. 2, 24-30.

AOAC, 1990. Official methods of analysis of the Association of Official Analytical Chemists (15th ed.). Association of Official Analytical Chemists, Washington D.C., USA. 
Ayadi, M. \& Casals R., 2009. First results on conjugated linoleic acid content of camel milk. In Proc. 2nd Conf. Int. Soc. of Camelids Res. and Develop. (ISOCARD), Djerba, Tunisia. pp, 47.

Ayadi, M., Matar, A., Aljumaah, R.S., Alshaikh, M.A. \& Abouheif, M.A., 2014. Evolution of udder morphology, alveolar and cisternal milk compartment during lactation and their relationship with milk yield in Najdi sheep. Span. J. Agric. Res.12, 1061-1070.

Ayadi, M., Such, X., Ezzehizi, N., Zouari, M., Najar, T., Ben, M'Rad. M. \& Casals, R., 2011. Relationship between mammary morphology traits and milk yield of Sicilo-Sarde dairy sheep in Tunisia. Small Rumin. Res. 96, 41-45.

Ayeb, N., Addis, M., Fiori, M., Khorchani, S., Atigui, M. \& Khorchani, T., 2015. Quality and fatty acid profile of the milk of indigenous goats subjected to different local diets in Tunisian arid lands. J. Anim. Physiol. Anim. Nutr. 41, 1-8.

Bouattour, M.A., Casals, R., Albanell, E., Such, X. \& Caja, G., 2007. Milk CLA and fatty acids profile in milk from Lacaune ewes fed whole safflower grains. Fifth International Symposium on the Challenge to Sheep and Goat Milk. I-P014. April 2007. Sardinia, Italy.

Castillo, V., Such, X., Caja, G., Casals, R., Salama, A.K. \& Albanell, E., 2009. Long- and short-term effects of omitting two-weekend milkings on the lactational performance and mammary tight junction permeability of dairy ewes. J. Dairy Sci. 92, 3684-3695.

Chilliard, Y., Ferlay, A., Mansbridge, R.M. \& Doreau, M., 2000. Ruminant milk fat plasticity: Nutritional control of saturated, polyunsaturated, trans and conjugated fatty acids. Ann. Zoo Tech. 49, 181-205.

De La Fuente, L.F., Barbosa, E., Carriedo, J.A., Gonzalo, C., Arenas, R., Fresno, J.M. \& San Primitivo, F., 2009. Factors influencing variation of fatty acid content in ovine milk. J. Dairy Sci. 92, 3791-3799.

Doney, J.M., Peart, J.N., Smith, W.F. \& Louda, F., 1979. A consideration of the techniques for estimation of milk yield by suckled sheep and a comparison of estimates obtained by two methods in relation to the effect of breed, level of production and stage of lactation. J. Agric. Sci. Camb. 92, 123-132.

Ellis, K.A., Innocent, G., Grove-White, D., Cripps, P., McLean, W.G., Howard, C.V.\& Mihm, M., 2006. Comparing the fatty acid composition of organic and conventional milk. J. Dairy Sci. 89,1938-1950.

Engels, W., Dekker, R., De Jong, C., Neeter, R. \& Visser, S., 1997. A comparative study of volatile compounds in the water-soluble fraction of various types of ripened cheese. Int. Dairy J. 7, 255-267.

Gargouri, A., Caja, G., Such, X., Ferret, A., Casals, R. \& Peris, S., 1993. Evaluation d'un systéme de traite et allaitement simultanés chez les brebis laitières de race Manchega. Fifth International Symposium on Machine Milking of Small Ruminants, Budapest. Hungarian J. Anim. Prod. 1, 484-499.

Kay, J.K., Weber, W.J., Moore, C.E., Bauman, D.E., Hansen, L.E., Hansen, L.B., Chester-Jones, H., Crooker, B.A. \& Baumgard, L.H., 2005. Effects of week of lactation and genetic selection for milk yield on milk fatty acid composition in Holstein cows. J. Dairy Sci. 88, 3886-3893.

Kelsey, J.A., Corl, B.A., Collier, R.A. \& Bauman, D.M., 2003. The effect of breed, parity, and stage of lactation on conjugated linoleic acid (CLA) in milk fat from dairy cows. J. Dairy Sci. 86: 2588-2597.

Kuchtík, J., Králičková, D.Z., Węglarzy, K. \& Šustová, I.S., 2015. Changes in physico-chemical characteristics, somatic cell count and fatty acid profile of Brown Short-haired goat milk during lactation. Anim. Sci. Pap. Rep. 33, 71-83.

Luna, P., Juárez, M. \& De la Fuente, M.A., 2005. Validation of a rapid milk fat separation method to determine the fatty acid profile by gas chromatography. J. Dairy Sci. 88, 3377-3381.

Marnet, P.G., 1997. Ewe management for improved milk yield and quality. Proceedings of the Third Great Lakes Dairy Sheep Symposium. Ramada Inn Capital Conference Center, Madison, Wisconsin, USA. Pp, 10-16.

Mierlita, D., Daraban, S. \& Lup, F., 2011a. Effects of breed on milk fatty acid profile in dairy ewes, with particular reference to cis-9, trans-11 conjugated linoleic acid. S. Afr. J. Anim. Sci. 441,223-231.

Mierlita, D., Hilma, E., Stelian, D. \& Lup, F., 2011b. Influence of lactation stage on milk yield and milk fatty acid profile in dairy ewes. Bulletin of University of Agricultural Sciences and Veterinary Medicine Cluj-Napoca. Anim. Sci. Biotech. 68, 217-224.

Nehdi, I.A., Sbihi, H., Tan, C.P. \& Al-Resayes, S.I., 2013. Evaluation and characterisation of Citrullus colocynthis (L.) Schrad seed oil: Comparison with Helianthus annuus (sunflower) seed oil. Food Chem. 136, 348-353.

Nudda, A., Bencini, R.S., Mijatovic, S. \& Pulina, G., 2002. The yield and composition of milk in Sarda, Awassi and Merino sheep milked unilaterally at different frequencies. J. Dairy Sci. 85, 2879-2884.

SAS. 2003. Users guide, Version 9.1, Statistical Analysis System Institute Inc., Cary, NC, USA

Signorelli, F., Contarini, G., Annicchiarico, G., Napolitano, F., Orrù, L., Catillo, G., Haenlein, G.F.W. \& Moioli, B., 2008. Breed differences in sheep milk fatty acid profiles: opportunities for sustainable use of animal genetic resources. Small Rumin. Res. 78, 24-31.

Sinanoglou, V.J., Koutsouli, P., Fotakis, C., Sotiropoulou, G., Cavouras, D. \& Bizelis, I., 2015. Assessment of lactation stage and breed effect on sheep milk fatty acid profile and lipid quality indices. Dairy Sci. Technol. 95, 509-531.

Sretenovic, L.J., Pantelic, V. \& Novakovic, Z., 2009. Importance of utilization of omega-3 fatty acids in human and animal nutrition. Biotech. Anim. Husb. 25, 439-449.

Ulbricht, T.L.V.\& Southgate, D.A.T., 1991. Coronary heart disease: seven dietary factors. Lancet. 338, 985-992.

Van Soest, P.V., Robertson, J.B. \& Lewis, B.A., 1991. Methods for dietary fiber, neutral detergent fiber, and non-starch polysaccharides in relation to animal nutrition. J. Dairy Sci. 74, 3583-3597.

Wang, T., Oh, J.J., Lim, J.N., Hong, J.E., Kim, J.H., Kang, H.S., Choi, Y.J., Lee, H.G., 2013. Effects of lactation stage and individual performance on milk cis-9, trans-11 conjugated linoleic acids content in dairy cows. AsianAustralas. J. Anim. Sci. 26, 189-194.

Yılmaz, O., Çak, B. \& Bolacalı, M., 2011. Effects of lactation stage, age, birth type and body weight on chemical composition of Red Karaman sheep milk. Kafkas. Univ. Vet. Fak. Derg.17, 383-386. 